\title{
Soil Organic Carbon Pools and Microbial Population in Extremely Saline Soils: A Case Study in Salt Desert of Rann of Kachchh, India
}

\author{
Ashim Datta, Arun Kumar Roy Mahato, Madhu Choudhary, Nisha, Priyanka, H.S. Jat, and P.C. Sharma
}

\section{ABSTRACT}

Saline soils are not suitable for plant growth due to higher osmotic potential and impair crop productivity to a great extent. Globally vast tract of land in arid and semiarid regions are affected by salinity and hardly supports any economic activities. Soil acts as the largest sink of terrestrial carbon and can help in climate change mitigation through sequestration of organic carbon. Therefore, an attempt has been made to assess the carbon concentration as well as microbial activity of soils of Rann of Kachchh (salt desert), Gujarat, India. The soil and water samples were found dark black in colour and the water was extremely saline (electrical conductivity $>700 \mathrm{dS} \mathrm{m}^{-1}$ ) in nature. Results showed that the total carbon and oxidizable organic carbon concentration was 7.1 and $5.3 \mathrm{~g} \mathrm{~kg}^{-1}$ at 0-15 cm soil depth. About $25.4 \%$ of the total carbon was present in recalcitrant form. We calculated that the salt desert of Rann of Kachch stored about $\sim 3640$ ton carbon at $0-15 \mathrm{~cm}$ soil depth. Fungi were absent and bacteria and actinomycetes were found in those soils. These highly saline soils of Rann of Kachchh can serve as a great sink for carbon sequestration with higher stability and help to achieve the goal of "4 per 1000" initiative.

Keywords: Arid environment, carbon sequestration, microbial activity, Rann of Kachchh, salinity.

\section{INTRODUCTION}

Accelerated greenhouse gas (GHG) emissions, temperature rise and its associated harmful impacts on agriculture production are the major concerns of $21^{\text {st }}$ century. Furthermore, soil degradation via salinity, sodicity, acidity, erosion etc. makes these concerns more complex particularly in arid and semiarid environments. Soil acts as a sink for terrestrial $\mathrm{C}$ and contains a stock of carbon to the tune of $2500 \mathrm{Gt}\left(1 \mathrm{Gt}=10^{9} \mathrm{t}\right)$, out of which soil organic and inorganic carbon constitute about $1550 \mathrm{Gt}$ and $950 \mathrm{Gt}$, respectively up to $1-\mathrm{m}$ depth [1]. The main source of crop nutrition is the labile $\mathrm{C}$ pool which influences the quality and productivity of soil [2]. Soils play a crucial role in determining the climate change impact on terrestrial ecosystems and in regulating GHG concentrations in the atmosphere. According to FAO Land and Nutrition Management Service [3], over $6 \%$ of the world's land is
Published Online: June 20,2020

ISSN: $2684-446 \mathrm{X}$

DOI : 10.24018 /ejgeo.2020.1.3.24

\section{Ashim Datta}

ICAR-Central Soil Salinity Research Institute, Karnal, Haryana, India

(e-mail: ashimdatta2007@gmail.com)

Arun Kumar Roy Mahato

Gujarat Institute of Desert Ecology,

Bhuj, Gujarat, India

(e-mail: akroymahato@gmail.com)

Madhu Choudhary

ICAR-Central Soil Salinity Research

Institute, Karnal, Haryana, India

(e-mail: madhucssri@gmail.com)

Nisha

ICAR-Central Soil Salinity Research

Institute, Karnal, Haryana, India

(e-mail: wadhwanisha2703@gmail.com)

Priyanka

ICAR-Central Soil Salinity Research Institute, Karnal, Haryana, India

(e-mail: priyankakaulash95@gmail.com)

H.S. Jat

ICAR-Central Soil Salinity Research Institute, Karnal, Haryana, India

(e-mail: hsjat_agron@yahoo.com)

P.C. Sharma*

ICAR-Central Soil Salinity Research

Institute, Karnal, Haryana, India

(e-mail: pcsharma.knl@gmail.com)

*Corresponding Author affected by the salinity, which accounts for more than 800 million hectare ( $\mathrm{M} \mathrm{ha}$ ) of land in 100 countries mostly in arid and semiarid regions. Among degraded soils, saline soils have significant potential for $\mathrm{C}$ sequestration in aboveground biomass and in the soil organic carbon (SOC) [4]. Moreover, future projections of climate change and increases in human population suggest that the extent of saline soils will increase [5]. Setia et al. [6] estimated $397 \mathrm{M}$ ha $(3.1 \%)$ of soil resources affected by soil salinization worldwide. With the extent of saline soils predicted to increase in the future, modeling of Setia et al. [6] suggests that world soils may lose $6.8 \mathrm{Pg}$ SOC due to salinity by the year 2100. In India $6.73 \mathrm{M}$ ha area is salt-affected of which saline and sodic soils account for approximately 2.76 and 3.97 million hectare, respectively hindering growth of crops in many extents, thereby posing a serious threat to food production of the country resulting in losses of 230 billion INR every year [7]. The estimate indicates that the area 
under salt affected soils in India will expand to $15.5 \mathrm{M}$ ha by 2030 [8].

There is projection that the global mean sea level will rise between $0.26-0.55 \mathrm{~m}$ and $0.45-0.82 \mathrm{~m}$ under the lowest and highest proposed GHG concentration scenarios, respectively, by 2100 [9]-[11]. Tidal wetlands spread over an area of ca. 538,000-552,000 $\mathrm{km}^{2}$ [12], and played a crucial role in many ecosystem functions such as water purification, biodiversity conservation, wildlife habitat, and shorelines protection along the coasts and estuaries [11]. Due to their efficient carbon (C) sequestration capacity at a rate of $0.0426 \mathrm{Gty}^{-1}$, tidal wetlands are also one of the most important global carbon pools [13]. Wetlands store an estimated $45-70 \%$ of all terrestrial C [14] [15]; making them important targets for conservation and major players in the global C cycle [12]. Carbon sequestration in marsh soils is a vital ecosystem process that contributes to the burial of carbon, also known as "blue carbon" [13] [14] [16] which will likely be altered in response to future environmental conditions driven by climate change and coastal restoration activities [17]. One of the reasons for the high $\mathrm{C}$ sequestration rate of wetlands is slower decomposition rate in water-saturated anaerobic soils [18]. Higher salinity has been reported to both increase [19] [20], and decrease decomposition rates in wetland ecosystems [21] [22] thereby highlighting the need for a more mechanistic understanding of how salinity affects carbon sequestration in soil.

Microorganisms are affected by salinity due to lower osmotic potential that resulted in reducing their activity and altering the composition of microbial community [23]. In saline soils, the SOC content is influenced by two opposing factors: reduced plant inputs which may decrease SOC, and reduced rates of decomposition (and associated mineralisation of organic $\mathrm{C}$ to $\mathrm{CO}_{2}$ ) which could increase SOC content if the $\mathrm{C}$ input was unchanged.

Globally as well as in south Asia, studies on sequestering atmospheric carbon have been focused mainly on forest, grassland and farmland soils, with little knowledge on soil carbon sequestration and microbial activity in saline soils of extremely arid regions. Due to the good soil structure saline soils can retain organic carbon for longer time (higher mean residence time) due to physical encapsulation mechanism [24]. Recently, there is a " 4 per 1000" initiative emerged in Conference of Parties (COP21) of United Nations Framework Convention on Climate Change (UNFCCC)[25]. It says increasing the carbon content of the world's soils by just a few parts per thousand (0.4\%) each year would remove an amount of $\mathrm{CO}_{2}$ from the atmosphere equivalent to the fossil-fuel emissions of the European Union (around 3-4 Gt) [25]. The Rann of Kachchh, the salt desert is situated in western part of Gujarat, India could be a great sink for long term storage of carbon in stable form. Therefore, we attempted to study the organic carbon pools and microbial population of extremely saline soils of Rann of Kachchh to estimate the carbon sequestration potential. Also analyse the characteristics of saline water collected from the salt desert.

\section{MATERIALS AND METHODS}

\section{A. Site description}

The soil and water samples for the present investigation were collected from a site $\left(23^{\circ} 50^{\prime} 36.50^{\prime \prime} \mathrm{N}\right.$ and $69^{\circ} 31^{\prime}$
05.62" E) in the Rann of Kachchh near to Dhordo village of Kachchh district, Gujarat which is popularly known as 'White Desert' (Fig. 1).

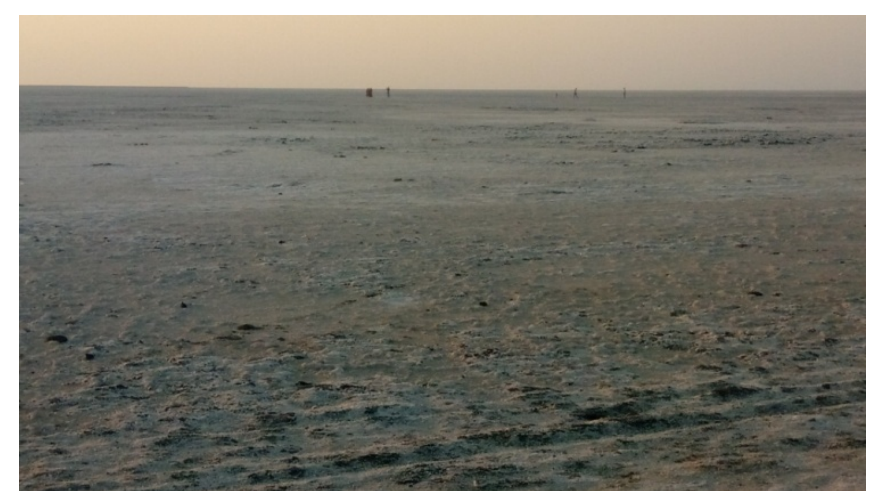

Fig. 1. The Rann of Kachchh with salt accumulation at soil surface

The Rann of Kachchh is an ecologically unique landscape which is geo-morphologically categorized as saline marshy desert, located in the extreme western part of India (Fig. 2).

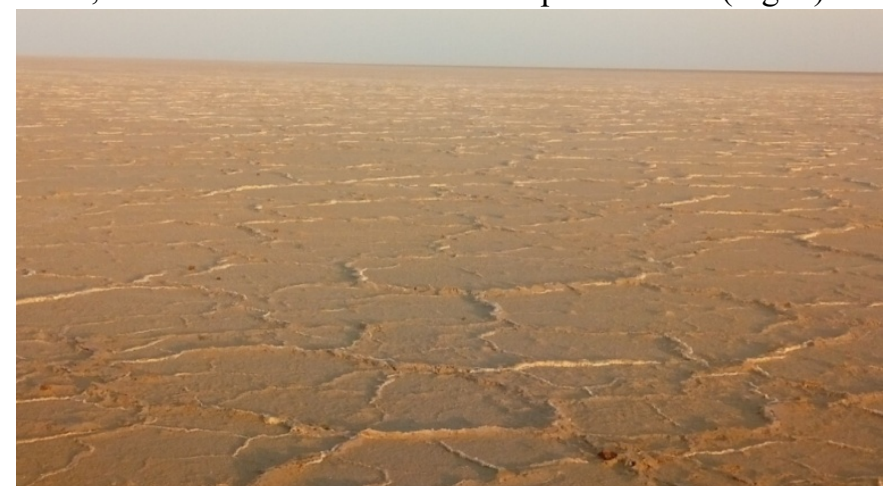

Fig. 2. The Rann of Kachchh with sporadic salt accumulation at surface soil

The Rann of Kachchh entirely falls under the Arid Biogeographic Zone of the country and spread in an area of 23310 sq. Km [26]. The climate is extremely arid with high temperature reaches to a maximum of $48-49^{\circ} \mathrm{C}$ during MayJune and goes down to $10^{\circ} \mathrm{C}$ during the month of January. The average humidity is about $60 \%$ with highly erratic average annual rainfall of $326 \mathrm{~mm}$.

\section{B. Geo-morphology and Evolution of Rann of Kachchh}

The Ranns of Kachchh are flat salt-covered desert areas (sabkhas) which are just above the normal tidal range and may be regarded as supratidal flats. The Rann, a unique geomorphic entity, a saline or salt encrusted wasteland comprises a flat hyper saline terrain that opens up to the Arabian Sea in the west [27]. It is a mysterious and fascinating tectonic landscape generated during last 10,000 years, in an area marked by sea-level changes [28]. Rann is the remnant of a very late marine transgression of Miocene Epoch, which is undergoing rapid siltation. The receding sea level, neo-tectonic activity and silting by the rivers have been attributed as the causes for the formation and transformation of this land mass, which remains under the influence of seasonal flooding by precipitation and occasional high tidal waves. Large part of the Rann surface gets inundated by storm tides from the tidal water from Arabian Sea lies in the west and the rest by annual southwest monsoon precipitation [29].

The Great Rann is sites of deposition of early Holocene sediments under estuarine deltaic environment. From Indus and Nara rivers which used to flow into the western end of 
the Great Rann, the sediments of the Ranns were probably once derived [30] [31]. Clay is now probably carried in by the rivers of Kachchh and Kathiawar during monsoon. Some sand and silt is blown into the Ranns from the surrounding hilly areas. The majority of Rann area is flooded during supra-tidal time, which does not go back to the sea and make salt playa environment which gives rise to permanent salt encrustation to the regions [29]. Maurya et al. [27] found the presence of shallow marine foraminifera throughout and presence of organic-rich carbonaceous material in the form of dispersed/scattered particles and suggest that the Rann surface is a result of continuous sedimentation for a long period of time, which highlighted that Rann was an embayed shallow gulf in the past.

C. Collection and analysis of soil and water samples Soil and water samples were collected from $0-15 \mathrm{~cm}$ soil depth during November, 2018 from three places (Fig. 3, 4).

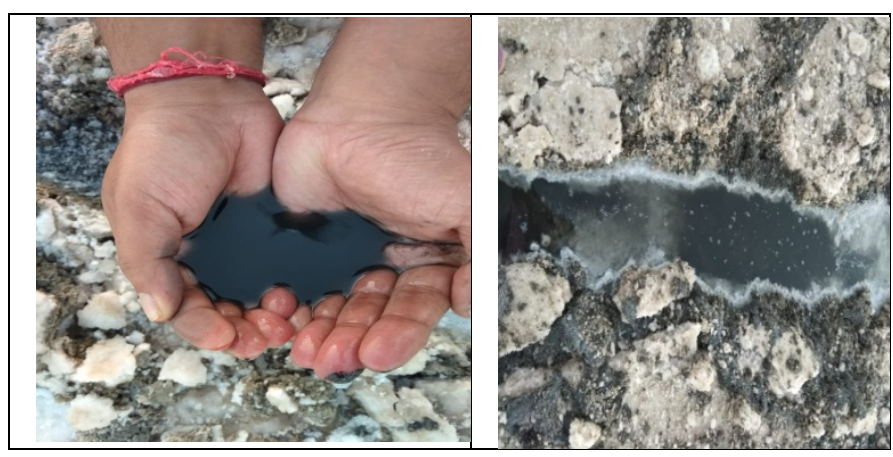

Fig. 3. Dark color water found below the soil-salt layer in the Rann of Kachchh

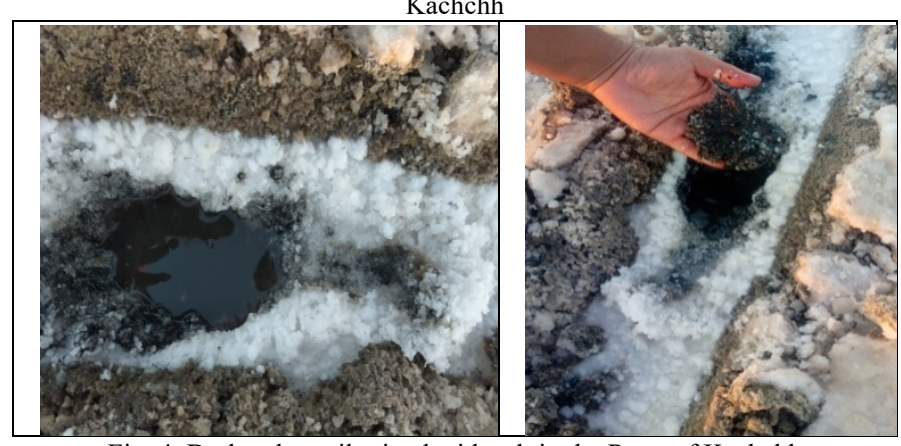

Fig. 4. Dark color soil mixed with salt in the Rann of Kachchh

Soil samples were air dried, ground and sieved with a 2.0 $\mathrm{mm}$ sieve. Another part of fresh soil was kept in freeze at $4^{\circ} \mathrm{C}$ for soil microbial analysis. Soil $\mathrm{pH}$ and electrical conductivity (EC) in soil: water ratio of 1:2 was determined by following standard methods [32]. The oxidizable organic carbon (OC) content of the soils was determined using wet oxidation method [33]; very labile carbon was measured by using $12 \mathrm{~N} \mathrm{H}_{2} \mathrm{SO}_{4}$ (Datta et al. 2018) [34]; total carbon (C) concentration was estimated by EuroEA Elemental Analyser. Recalcitrant carbon was calculated after subtracting oxidizable organic carbon [33] from total carbon. Assuming the weight of one hectare $\left(10,000 \mathrm{~m}^{2}\right)$ furrow slice at $0-15 \mathrm{~cm}$ soil depth as $2.2 \times 10^{6} \mathrm{~kg}$ [35], we calculated the total carbon concentration of $23310 \mathrm{~km}^{2}$ area of the Rann of Kachch. As we did not measure soil bulk density, we were unable to calculate the SOC stock.

For the microbial population count, dilutions were performed in two ways- dilution in distilled water and dilutions in distilled water $+10 \% \mathrm{NaCl}$. Microbial counts were done on different types of media. Bacterial count was done on nutrient agar (NA), for the fungal colony count, potato dextrose agar (PDA) was used and actinomycetes count was done on actinomycetes isolation agar (AIA) [36].

D. Data Analysis

A general linear model (GLM) was fitted using the GLM procedure from SPSS Windows version 16.0 (SPSS Inc., Chicago, USA). Mean values for different parameters were separated by Duncan Multiple Range Test at 5\% level of significance $(p<0.05)$. Other statistical analysis was carried out in MS Excel to determine the mean and standard error of the mean.

\section{RESUlTS}

Results showed that the soils were extremely saline in nature. Soil $\mathrm{pH}$ was 8.01 (with standard error of mean \pm 0.05 ) and EC was $316( \pm 40.8) \mathrm{dS} \mathrm{m}^{-1}$ at $0-15 \mathrm{~cm}$ soil depth. Total carbon of the soil was $7.1 \mathrm{~g} \mathrm{~kg}^{-1}( \pm 0.12)$ at $0-15 \mathrm{~cm}$ soil depth. On this basis the total carbon concentration of the whole area $\left(23310 \mathrm{~km}^{2}\right)$ of Rann of Kachch was $\sim 3640$ ton at $0-15 \mathrm{~cm}$ soil depth. Very labile carbon concentration was $1.5 \mathrm{~g} \mathrm{~kg}^{-1}( \pm 0.08)$ whereas oxidizable organic carbon concentration was $5.3 \mathrm{~g} \mathrm{~kg}^{-1}( \pm 0.09)$ at $0-15 \mathrm{~cm}$ soil depth. On average, about $21 \%$ of the total carbon resided in very labile pool whereas recalcitrant carbon constituted about $25 \%$ of total carbon. Analysis of water samples showed that the water was also extremely saline with EC of $729 \mathrm{dS} \mathrm{m}^{-1}$ and $\mathrm{pH}$ of 6.69. $\mathrm{Na}^{+}, \mathrm{K}^{+}, \mathrm{Ca}^{2+}$ and $\mathrm{Mg}^{2+}$ ion concentration of the water samples were 5956, 328, 2, 92 me $\mathrm{L}^{-1}$, respectively whereas $\mathrm{HCO}_{3}^{-}, \mathrm{Cl}^{-}$and $\mathrm{SO}_{4}{ }^{2-}$ were 5, 5800, and $575 \mathrm{me} \mathrm{L}^{-1}$, respectively.

Sodium chloride $(\mathrm{NaCl})$ was added in the dilution for minimising the osmotic shock and stimulating similar condition as microbes were facing in natural conditions in Rann of Kachchh. With distilled water, bacterial population ranged from $30 \times 10^{2}$ to $20 \times 10^{3}$ c.f.u g g ${ }^{-1}$ soil and $17 \times 10^{3}$ to $36 \times 10^{3}$ c.f.u $\mathrm{g}^{-1}$ soil with distilled water and $10 \% \mathrm{NaCl}$ (Table 1). No fungal colony was observed in these soil samples. In one sample actinomycetes population was detected and varied from 35 to $37 \times 10^{3}$ c.f.u g ${ }^{-1}$ soil with distilled water and $10 \% \mathrm{NaCl}$.

\section{DISCUSSION}

Due to decreased plant biomass, the organic matter inputs are reduced in saline soils. Microbial activity is affected by $\mathrm{C}$ inputs via plant parts and therefore it can influence organic matter decomposition rates. In spite of absence of any plant $\mathrm{C}$ input to soil of the salt desert (Fig. 1, 2), the soils contained considerable amount of total carbon $(0.71 \%)$ and medium range of oxidizable organic carbon $(>0.50 \%)$ which might be due to the deposition of early Holocene sediments under estuarine deltaic environment [29] and the sediments of Ranns which was probably derived from the Indus and Nara rivers used to flow in that area [37] as evidenced from the very dark colour of the soil and water (Fig. 4). Higher salt concentration improved the soil structure with good aggregation [24] which can retain organic carbon inside the microaggregates for longer time in absence of decomposition due to lower microbial activity (Fig. 5) thereby explaining significant amount (on average $25.4 \%$ ) of total carbon in recalcitrant form. Moreover, very dark colour of the soil indicates that the carbon may be more stable and cannot be easily oxidized due to extreme salinity 
of the soil and water [24] which prohibits the growth of microorganisms as revealed from Table 1. More studies are required to reach any robust conclusion regarding the stability of the carbon in salt desert.

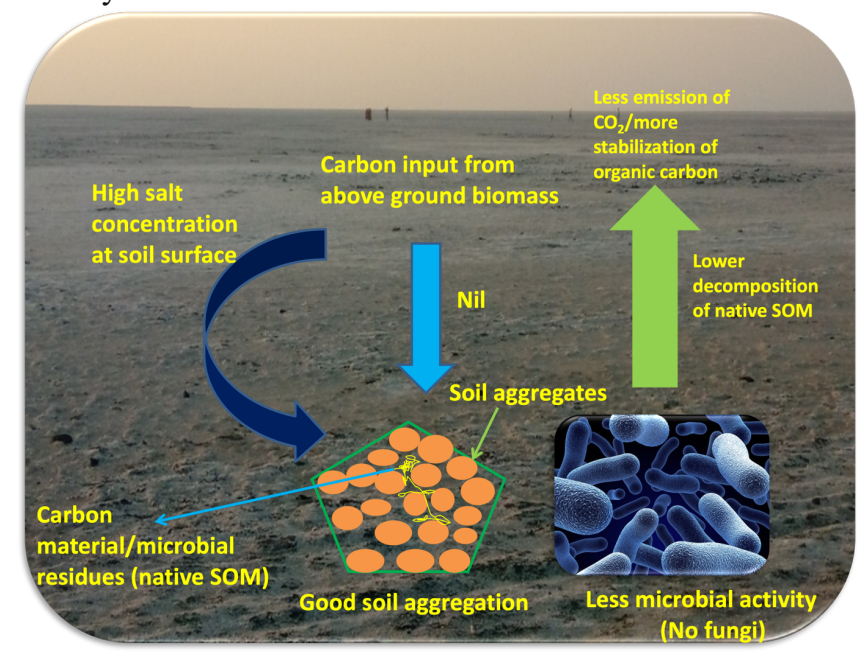

Fig. 5. Schematic diagram showing mechanism of carbon stabilization in extremely saline soils of Rann of Kachch

TABLE 1: MICROBIAL POPULATION IN SALINE SOILS OF RANN OF KACHCHH

\begin{tabular}{llll}
\hline SAMPLE & Microbial count & Dilution & c.f.u g ${ }^{-1}$ soil \\
\hline S-1 & Bacteria & DW & $30 \times 10^{2} \mathrm{aA}$ \\
& & $\mathrm{DW}+10 \% \mathrm{NaCl}$ & $17 \times 10^{3} \mathrm{bB}$ \\
\cline { 2 - 4 } & Fungi & $\mathrm{DW}$ & $\mathrm{ND}$ \\
& & $\mathrm{DW}+10 \% \mathrm{NaCl}$ & $\mathrm{ND}$ \\
\cline { 2 - 4 } & Actinomycetes & $\mathrm{DW}$ & $\mathrm{ND}$ \\
& Bacteria & $\mathrm{DW}+10 \% \mathrm{NaCl}$ & $\mathrm{ND}$ \\
\hline S-2 & Fungi & $\mathrm{DW}+10 \% \mathrm{NaCl}$ & $20 \times 10^{3} \mathrm{bB}$ \\
& & $\mathrm{DW}+10 \% \mathrm{NaCl}$ & $\mathrm{ND}$ \\
& & $\mathrm{DW}$ & $\mathrm{ND}$ \\
\cline { 2 - 4 } & Actinomycetes & $\mathrm{DW}+10 \% \mathrm{NaCl}$ & $37 \times 10^{3} \mathrm{a}$ \\
& & $(\mathrm{b}) \mathrm{and}$ \\
\hline
\end{tabular}

Values with different lower case $(\mathrm{a}, \mathrm{b})$ and upper case $(\mathrm{A}, \mathrm{B})$ letters are significantly different between dilutions for each microorganism and between microorganisms for each soil sample, respectively, at $\mathrm{P}<0.05$ (Duncan multiple range tests for separation of mean). (c.f.u: colony forming unit; DW: distilled water)

Lower osmotic potential of soil water outside of the cells is the main problem encountered by microorganisms in saline soils, which results cells to lose water. Archaea, Bacteria and Eucarya are the salinity-resistant microorganisms which can rapidly accumulate salts to adjust their intracellular osmotic potential [38]. The organic solutes synthesis and $\mathrm{Na}$ extrusion from the cells of microorganisms require up to three times more energy than cell wall synthesis [38]. Indeed, with increasing salinity $\mathrm{C}$ utilization efficiency (conversion of substrate $\mathrm{C}$ into microbial biomass) decreases [39], resulting in greater $\mathrm{CO}_{2}$ release per $\mathrm{g}$ substrate $\mathrm{C}$. Microbial community structure is affected by salinity as shown by earlier studies[40]-[42] and fungi were more sensitive to salinity than bacteria [40] [41]. This may have important implications for organic matter decomposition because fungi play a key role in decomposition of polymeric plant and animal residues as well as recalcitrant compounds such as lignin [43]. Salinity decreased SOC mineralization [44] [45]. In salt-affected soils, $\mathrm{C}$ and $\mathrm{N}$ mineralization was inhibited at higher $\mathrm{EC}$ with nitrification being more sensitive than ammonification [46] [47]. Setia et al. [48] also found that EC was the main factor influencing soil respiration in salt-affected soils. Bacteria and actinomycetes were found higher when $\mathrm{NaCl}$ was added to the dilution. It may be because microbes were originally surviving in high saline soils and they are adapted to that environment of high salt. Fungi are more sensitive to osmotic stress than bacteria [49] hence they were not detected in highly saline soils. Chowdhury et al. [23] also showed that microbial activity in saline soils was more strongly decreased by decreasing osmotic potential at given water content.

\section{CONCLUSIONS}

Therefore, in terms of SOC storage with long term stability these salt affected lands in extremely arid regions would be a great option for climate change mitigation and at the same time perform many ecosystem functions through $\mathrm{C}$ sequestration in soil and meet the sustainable development goals. More research on the mechanisms underlying the stability of organic carbon in salt desert and salinity's regulation of enzyme activity and decomposition is needed to quantitatively predict salinity-induced changes in soil $\mathrm{C}$ cycling.

\section{ACKNOWLEDGMENT}

The authors are thankful to Mrs. Sudha Mehta and Subhamita Das for their help received during collection of soil and water samples. Authors are grateful to the Director, ICAR-CSSRI for providing necessary facilities during the analysis of the soil and water samples.

\section{REFERENCES}

[1] R. Lal, "Soil carbon sequestration impacts on global climate change and food security," Science, vol. 304, pp. 1623-1627, 2004.

[2] A. J. Nath, T. Bhattacharyya, S. K. Ray, J. Deka, A. K. Das \& H. Devi, "Assessment of rice farming management practices based on soil organic carbon pool analysis," Tropical Ecology, vol. 57(3), pp. 607-611, 2016.

[3] FAO, "Land and Plant Nutrition Management Services," 2008. http://www.fao.org/agb/agl/agll/spush/

[4] R. Lal, "World cropland soils as a source or sink for atmospheric carbon," Advances in Agronomy, vol. 71, pp.145-191, 2001.

[5] P. Rengasamy, "Salinity in the landscape: A growing problem in Australia," Geotimes, vol.53, pp. 34-39, 2008.

[6] R. Setia, P. Gottschalk, P. Smith, P. Marschner, J. Baldock, D. Setia \& J. Smith, "Soil salinity decreased global soil organic carbon stocks," Sci. Tot. Environ., vol. 465, pp. 267-272, 2013.

[7] D. K. Sharma, K. Thimmppa, A. R. Chinchmalatpure, A. K. Mandal, R. K. Yadav, S. K. Chaudhari, S. Kumar \& A. K. Sikka, "Assessment of Production and Monetary Losses from Salt-affected Soils in India," Technical Bulletin: ICARCSSRI/ Karnal/2015/05. ICAR-Central Soil Salinity Research Institute, Karnal, India, 2015.

[8] Central Soil Salinity Research Institute (CSSRI), Vision 2050, CSSRI, Karnal, 2015.

[9] IPCC, Climate change, "The physical science basis. Contribution of Working Group I to the Fifth Assessment Report of the Intergovernmental Panel on Climate Change," Cambridge University Press, Cambridge, United Kingdom and New York, NY, USA, 2013.

[10] J. Hinkel, C. Jaeger, R. J. Nicholls, J. Lowe, O. Renn \& P. Shi, "Sealevel rise scenarios and coastal risk management," Nature Climate Change, vol. 5, pp. 188-190, 2015.

[11] M. Luo, J-F. Huang, W-F. Zhu \& C. Tong, "Impacts of increasing salinity and inundation on rates and pathways of organic carbon mineralization in tidal wetlands: a review," Hydrobiologia, vol. 827, pp. 31-49, 2019.

[12] E. Mcleod, G. L. Chmura, S. Bouillon, R. Salm, M. Bjork, C. M. Duarte, C. E. Lovelock, W. H. Schlesinger \& B. R. Silliman, "A blueprint for blue carbon: toward an improved understanding of the role of vegetated coastal habitats in sequestering CO2," Frontiers in Ecology and the Environment, vol. 9, pp. 552-560, 2011. 
[13] G. L. Chmura, S. C. Anisfeld, D. R. Cahoon \& J. C. Lynch, "Global carbon sequestration in tidal, saline wetland soils," Global Biogeochemical Cycles, vol. 17, pp. 1-12, 2003.

[14] S. Mitra, R. Wassmann \& P. L. Vlek, "An appraisal of global wetland area and its organic carbon stock," Current Science, vol. 88, pp. 25-35, 2005.

[15] E. M. Morrissey, J. L. Gillespie, J. C. Morina \& R. B. Franklin, "Salinity affects microbial activity and soil organic matter content in tidal wetlands," Global Change Biology, vol. 20, pp. 1351-1362, 2014.

[16] C. S. Hopkinson, W-J. Cai \& X. Hu., "Carbon sequestration in wetland dominated coastal systems - a global sink of rapidly diminishing magnitude," Current Opinion in Environmental Sustainability, vol. 4, pp. 186-194, 2012.

[17] M. M. Baustian, C. L. Stagg, C. L. Perry, L. C. Moss, T. J. B. Carruthers \& M. Allison, "Relationships between salinity and shortterm soil carbon accumulation rates from marsh types across a landscape in the Mississippi River Delta," Wetlands, vol. 37, pp. 313-324, 2017

[18] K. R. Reddy, R. D. DeLaune, "Coastal wetlands: Mississippi River deltaic plain coastal marshes, Louisiana," Biogeochemistry of Wetlands: Science and Applications, pp. 669-702. CRC Press, Boca Raton, 2008.

[19] N. B. Weston, R. E. Dixon \& S. B. Joye., "Ramifications of increased salinity in tidal freshwater sediments: geochemistry and microbial pathways of organic matter mineralization," J. Geophys. Res., vol. 111, pp. 2005-2012, 2006.

[20] C. Craft, "Freshwater input structures soil properties, vertical accretion, and nutrient accumulation of Georgia and US tidal marshes," Limnology and Oceanography, vol. 52, pp. 1220-1230, 2007.

[21] M. C. Roache, P. C. Bailey \& P. I. Boon, "Effects of salinity on the decay of the fresh water macrophyte, Triglochin procerum," Aquatic Botany, vol. 84, pp. 45-52, 2006.

[22] S. C. Neubauer, "Ecosystem responses of a tidal freshwater marsh experiencing saltwater intrusion and altered hydrology," Estuaries and Coasts, vol. 36, pp. 491-607, 2012.

[23] N. Chowdhury, P. Marschner \& R.G. Burns, "Soil microbial activity and community composition: Impact of changes in matric and osmotic potential," Soil Biology and Biochemistry, vol. 43, pp. 1229-1236, 2011.

[24] A. Datta, R. Setia, A. Barman, Y. Guo \& N. Basak, "Carbon Dynamics in Salt-Affected Soils" In: J.C. Dagar, R.K. Yadav and P.C. Sharma (eds) Research Developments in Saline Agriculture, Springer India. Pp. 1-20, 2019.

[25] B. Minasny, B. P. Malone, A. B. McBratney, D. A. Angers, D. Arrouays, A. Chambers, et al., "Soil carbon 4 per mille," Geoderma, vol. 292, pp. 59-86, 2017.

[26] V. Kumar, A. K. R. Mahato \& N. Patel, "Rann of Kachchh," In State of Environment Report 2012 Ed. A.K.Verma, Gujarat Ecology Commission, Gandhinagar, pp. 53, 2012.

[27] D. M. Maurya, N. Khonde, A. Das, V. Chowksey \& L. S. Chamyal, "Subsurface sediment characteristics of the Great Rann of Kachchh, western India based on preliminary evaluation of textural analysis of two continuous sediment cores," Current Science, vol. 104(8), pp. 1071-1077, 2013.

[28] S. S. Merh, "The Great Rann of Kachchh: Perceptions of a field geologist," Journal of the Geological Society of India, vol. 65(1), pp. 9-25, 2005.

[29] B. Roy, S. S. Merh, "The Great Rann of Kutch: an intriguing Quaternary terrain," Recent Research in Geology, vol. 29, pp. 519$539,1982$.

[30] B. Roy, "Pattern and causes of inundation of Rann of Kutch", Ph.D. Thesis M. S. University of Baroda, Vadodara, 1973.

[31] B. Roy, S. S. Merh, "Geomorphology of the Rann of Kutch and climatic changes," Ecology and Archeology of W. India, Ed. Agrawal, D.P. and Pande, B.M. ocept Pu. Co., Delhi, pp. 195-200, 1977

[32] M. L. Jackson, "Soil chemical analysis," New Delhi, Prentice Hall of India Pvt. Ltd., 1973.

[33] A. Walkley, I. A. Black, "An experiment of the Degtareff method for determination of soil organic matter and a proposed modification of the chronic acid titration method," Soil Sci., vol. 37, pp. 29-38, 1934.

[34] A. Datta, B. Mandal, S. Badole, A. K. Chaitanya, S. P. Majumder, D. Padhan, N. Basak, A. Barman, R. Kundu \& W. Narkhede, Interrelationship of biomass yield, carbon input, aggregation, carbon pools and its sequestration in Vertisols under long term sorghumwheat cropping system in semi-arid tropics," Soil and Tillage Research, vol. 184, pp. 164-175, 2018.
[35] N. C. Brady, R. R. Weil, "The Nature and Properties of Soils," 14th edition. Prentice-Hall, Upper Saddle River, New Jersey, 2007.

[36] Himedia Manual, "HiMedia Manual for microbiology laboratory practice," HiMedia Laboratories Pvt. Ltd, India, 2009.

[37] K. W. Glennie, G. Evans, "A reconnaissance of the recent sediments of the Ranns of Kutch, India," Sedimentology, vol. 23, pp. 625-647, 1976.

[38] A. Oren, "Bioenergetic aspects of halophilism," Microbiol. Mol. Biol. Rev., vol. 63, pp. 334-348, 1999.

[39] D. Rietz, R. Haynes, "Effects of irrigation-induced salinity and sodicity on soil microbial activity," Soil Biol. Biochem., vol. 35, pp. 845-854, 2003.

[40] C. Pankhurst, S. Yu, B. Hawke, B. Harch, "Capacity of fatty acid profiles and substrate utilization patterns to describe differences in soil microbial communities associated with increased salinity or alkalinity at three locations in South Australia," Biol. Fertil. Soils, vol. 33, pp. 204-217, 2001.

[41] R. Gros, F. Poly, L. J. Monrozier, P. Faivre, "Plant and soil microbial community responses to solid waste leachates diffusion on grassland," Plant Soil, vol. 255, pp. 445-455, 2003.

[42] R. Setia, P. Smith, P. Marschner, P. Gottschalk, J. Baldock, V. Verma, D. Setia, J. Smith, "Simulation of salinity effects on soil organic carbon: past, present and future carbon stocks," Environ. Sci. Technol., vol. 46, pp. 1624-1631, 2012.

[43] K. Killham, "Soil ecology," Cambridge University Press, Cambridge, 1994.

[44] R. Setia, P. Marschner, "Carbon mineralization in saline soils as affected by residue composition and water potential," Biol. Fertil. Soils, vol. 49, pp. 71-77, 2012.

[45] R. Setia, P. Marschner, "Impact of total water potential and varying contribution of matric and osmotic potential on carbon utilization in saline soils,” Eur. J. Soil Biol., vol. 56, pp. 95-100, 2013.

[46] G. McClung, W. Frankenberger, "Nitrogen mineralization rates in saline vs. salt-amended soils," Plant Soil, vol. 104, pp.13-21, 1987.

[47] G. Rasul, A. Appuhn, T. Müller, R. G. Joergensen, "Salinity-induced changes in the microbial use of sugarcane filter cake added to soil," Appl. Soil Ecol., vol. 31, pp. 1-10, 2006.

[48] R. Setia, P. Marschner, J. Baldock, D. Chittleborough, P. Smith, J. Smith, "Salinity effects on carbon mineralization in soils of varying texture," Soil Biol. Biochem., vol. 43, pp. 1908-1916, 2011.

[49] J. Wichern, F. Wichern, R. G. Joergensen, "Impact of salinity on soil microbial communities and the decomposition of maize in acidic soils" Geoderma, vol. 137, pp.100-108, 2006.

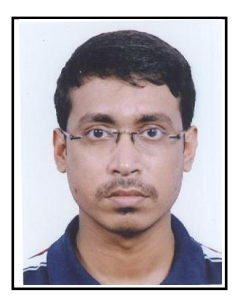

Ashim Datta holds Bachelor of Science degree in Agriculture in 2006; Master of Science in Agricultural Chemistry and Soil Science in 2009; and Doctor of Philosophy in Agriculture with specialization in Agricultural Chemistry and Soil Science in 2016. He is presently working as a Scientist (Soil Science) in the Division of Soil and Crop Management, ICAR-Central Soil Salinity Research Institute, Karnal, Haryana, India.

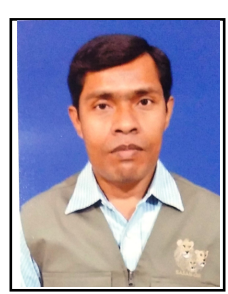

Arun Kumar Roy Mahato holds Bachelor of Science degree in Zoology in 1999; Master of Science in Zoology in 2002; and Doctor of Philosophy in Zoology with specialization in Ecology and Wildlife in 2008. He is presently working as a Senior Scientist in the Terrestrial Ecology Division, Gujarat Institute of Desert Ecology, Bhuj, Gujarat, India.

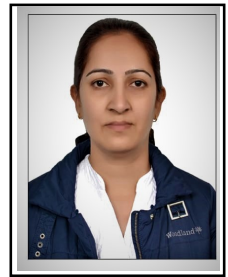

Madhu Choudhary holds Master degree in Agricultural Microbiology in 2004; and Doctor of Philosophy in Microbiology in 2016. She is presently posted as a Scientist in Division of Soil and Crop Management, ICAR-Central Soil Salinity Research Institute, Karnal, Haryana, India. Her research interest includes studies on metagenomics, plant growth promoting microbes and residue degrading microbes. 


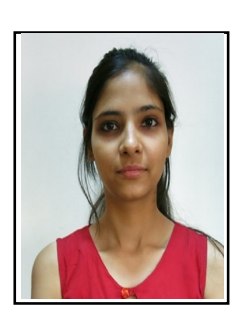

Ms. Nisha, a postgraduate student in Applied Microbiology and Biotechnology at the Banasthali University, Jaipur. Her research interest includes soil microbiology and food microbiology. She has two year of research experience in the field of soil microbiology. She has done dissertation work on Sulphur oxidising bacteria. She has presented poster in International conference at CSSRI, Karnal, Haryana, India.

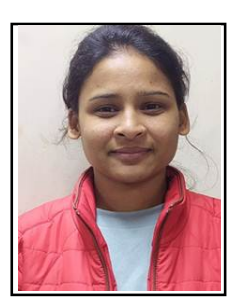

Ms. Priyanka holds Bachelor of Science degree in Basic Sciences in 2015; Master of Science in Environmental Sciences in 2017. She is presently working as an intern in CIMMYT-CCAFS project in the Division of Soil and Crop Management, ICARCentral Soil Salinity Research Institute, Karnal, Haryana, India.

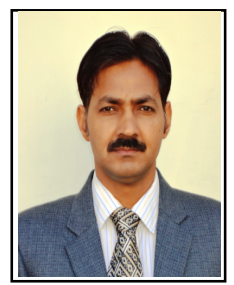

H.S. Jat holds Bachelor of Science degree in Agriculture in 1997; Master of Science in Agronomy in 1999; and Doctor of Philosophy in Agronomy with specialization in Crop Husbandry in 2003. He is presently working as a Principal Scientist (Agronomy) and leading the Conservation Agriculture program in the Division of Soil and Crop Management, ICAR- Central Soil Salinity Research Institute, Karnal, Haryana, India.

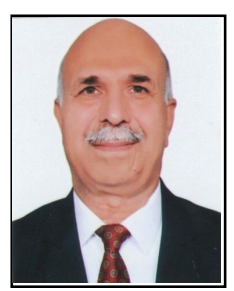

P.C. Sharma holds Master of Science in Plant Physiology in 1982; and Doctor of Philosophy in Plant Physiology in 1986. He has more than 30 years' research experience in understanding mechanism of salt tolerance in different crops and has developed eleven salt tolerant varieties of rice, mustard, wheat and lentil. Presently, he is working as Director, ICAR-Central Soil Salinity Research Institute, Karnal, Haryana, India. 